\title{
Google Classroom: Malaysian University Students' Attitudes towards Its Use as Learning Management System
}

\author{
Wan Zulkifli Wan Kassim
}

Universiti Malaysia Terengganu (UMT), Terengganu

*Corresponding author.Email: wanzul@umt.edu.my

\begin{abstract}
Education in the $21^{\text {st }}$ century is heavily influenced by information and communication technology. The advancement of the Internet has enabled learning to be conducted online, which offers many advantages. Online learning is commonly managed using a learning management system (LMS), the most widely used being Google Classroom. Studies have shown that Google Classroom's ease of use, usefulness, and helpfulness have been viewed by learners around the world positively. However, studies involving Malaysian learners are sparse. To close the gap in the literature, the present study examined Malaysian university students' attitudes towards the use of Google Classroom as LMS. Research method employed was quantitative descriptive research. Participants were 89 students from a public university in Terengganu, Malaysia, who were taking an English course. They were mostly female (71\%) and between 20 and 23 years old. They had attended face-to-face learning sessions for five weeks before the Covid-19 pandemic necessitated the classes to be held online completely. Participants then completed nine weeks of online learning on Google Classroom. To obtain participants' feedback, they were requested to fill out a Google Form questionnaire, which asked them to rate on a five-point Likert scale their perceptions of Google Classroom's ease of use and usefulness as well as their intention to continue using the platform. Based on the results, participants' views of Google Classroom were very positive. It can be suggested that participants found Google Classroom easy to use, useful, and worth using.
\end{abstract}

Keywords: Educational technology, Attitudes, Google Classroom

\section{INTRODUCTION}

Since education was first institutionalised in the $17^{\text {th }}$ century, it has over the years experienced substantial evolution. In the $21^{\text {st }}$ century, education has continued to evolve, it now being shaped by modern advances in information and communication technology, or ICT [1]. There are several ways how education can use ICT beneficially. ICT can be made part of the curriculum, used as a means to deliver instructions, incorporated to aid instructions, and used to make the overall learning process an improved experience [2]. ICT's integration into educational system has led to positive effects [3]. Classrooms with technology-assisted instructions can make learning and teaching not only more effective but also enjoyable [4]. These classrooms make students more motivated to learn about the subjects [4].
In higher education institutions, classrooms of this nature can contribute towards improved educational quality [5]. In language education, classrooms that use technology have been shown to produce positive results [6]-[8]. Technology-enhanced classrooms not only benefit students but also teachers [9].

With the advancement of the Internet technology, there have emerged new learning and teaching innovations. Instead of occurring in physical classrooms, learning can now take place online [10]. As defined by Singh and Thurman (2019) [11], online learning refers to "learning experiences in synchronous and asynchronous environments using different devices (e.g., mobile phones, laptops, etc.) with Internet access.” (p. 289). In recent years, the use of online learning in higher education has increased [12]. Such increase is mostly due to many 
advantages online learning offers over the traditional classroom environment. To mention a few, online learning allows learners to access instructional materials asynchronously at their own time, and it enables them to communicate with their instructors and coursemates via the Internet without the need for physical meetings [13]. Online learning is commonly managed through a Learning Management System (LMS), a web-based system that allows teachers and students to always be connected with each other [13]. LMS helps teachers to organize the online courses [14]. Through LMS, teachers can engage in several activities, such as communicate with students, share classroom materials, give quizzes and assignments, and mark and return assignments, while students can access materials, submit assignments, and interact with teachers and other students [15]. One of the more popular LMSs is Google Classroom. Across the globe, Google Classroom is used by thousands of schools and universities aiming to take advantage of its features to enhance their learning and teaching [3].

However, technology such as online learning is only as advantageous and effective as learners accepting and using it. Learners may not accept online learning as useful and refuse to utilize it, which makes its implementation a waste of time and resources. As such, learners' degree of acceptance of online learning needs to be determined. One of the pertinent models commonly used for this purpose is technology acceptance model [16].

Most studies by researchers in the field have shown that users of Google Classroom view its ease of use, usefulness, and helpfulness in a positive way [4];[17]-[21]. However, studies on Google Classroom involving Malaysian learners are sparse. Even sparser are studies that involved Malaysian students taking English subjects. Therefore, closing this gap in the literature was the aim of the present study.

The present study examined Malaysian university students' attitudes towards the use of Google Classroom as LMS. Research method employed was quantitative descriptive research, with data collected through a survey. The research questions were as follows:

1. Do students perceive Google Classroom as easy to use?

2. Do students perceive Google Classroom as useful? 3. Do students intend to use Google Classroom over other methods and platforms?

\section{LITERATURE REVIEW}

\subsection{Technology Acceptance Model}

Technology acceptance model, proposed by Davis (1989) [16], explains what motivate users to accept and subsequently use technology. According to Davis, users' attitudes towards technology are shaped by two factors: perceived ease of use and perceived usefulness. He defines perceived ease of use as "the degree to which a person believes that using a particular system would be free from effort" (p. 320). If a user believes it is easy to use a system, the user will end up using it. In contrast, if a user is discouraged by complicated design of a system, he or she will decide not to use it. As for perceived usefulness, Davis defines it as "the degree to which a person believes that using a particular system would enhance his or her job performance" (p. 320). If a user believes that a system can help him or her complete tasks quicker and with less effort, he or she will most likely decide to use it. On the other hand, if a user perceives a system as unable to enhance performance, the user may not be willing to accept and use the system.

\subsection{Google Classroom}

Google Classroom was developed by Google Inc for academic institutions and was publicly launched on 12 August 2014. Its main purpose is not only to allow teachers and students to share files efficiently, but enable teachers to create, distribute, and grade assignments online [22]. Within the system, teachers and students can engage in discussions, and teachers can monitor students' progress [23]. One of the main advantages of Google Classroom is that it is free [24]. It has also been shown that Google Classroom can influence students to become independent learners who study on their own [4];[25]. Heggart and Yoo (2018) [26] found that students strongly agreed to the use of Google Classroom in teaching and learning because they can access the information from the very same source through a variety of devices such as laptops, mobile phones or tablets any time. Saeed and Mostafa (2018) [27] found that when Google Classroom was integrated into their learning, students felt motivated. Khalil (2018) [28] found that students viewed Google Classroom as supporting collaborative learning environment since it allows teacher-student and student-student interactions.

\subsection{Students' Attitudes towards Google Classroom}

Most studies conducted in several different countries found students' attitudes towards Google Classroom to be positive. Hamzat (2020) [3] conducted a study involving male and female students taking different subjecs at several colleges in Nigeria. Based on the findings, it was found that students' attitudes towards Google Classroom were positive. A-Maroof and Al-Emran (2018) [29] examined the factors affecting learners' acceptance of Google Classroom at a university in Oman. From the results, they concluded that the use of Google Classroom is influenced by learners' perceived ease of use and usefulness. Sepyanda (2018) [21] aimed to discover the attitudes of students taking a translation subject at a university in Indonesia. From the questionnaire filled out by nine students, the researcher concluded that their attitudes towards Google Classroom belonged in the "good" category.

Few studies examined the attitudes of Malaysian learners towards Google Classroom. Abd Manan and Hanafi (2019) [20] sought to determine if Malaysian high school 
students were willing to accept Google Classroom as LMS for their Islamic Education subject. Based on the survey results, it was concluded that students found Google Classroom interesting and were willing to use it in their learning. Shaharanee, Jamil and Rodzi (2016) [30] conducted a study involving Malaysian university students taking a data mining subject to determine the effectiveness of Google Classroom in catering to the course. Based on the results, the researchers concluded that students were satisfied with the features on Google Classroom. In addition, unlike in traditional face-to-face classrooms, when on Google Classroom students admitted feeling more confident to actively engage in learning and teaching discussions.

Reinhardt et al. (2012) [31] argued that students' attitudes towards Google Classroom may differ depending on the type of their environments. Thus, while most findings have reported learners' positive perceptions, a few studies found contrasting results. Awuah (2015) [32] found that students did not rate their experience using Google Classroom as positive. However, the dissatisfaction with Google Classroom did not stem from the use of the system itself, but arose because of other factors including poor internet coverage, problems with devices, and lack of computer skills. Bhuvaneswari and Padmanaban (2012) [33] found that students did not rate Google Classroom highly because physical face-to-face communication between teachers and students was absent. Darma Putra (2018) [34] found that while some students perceived Google Classroom as useful and beneficial, others did not see it as offering better learning, and while learning on Google Classrom they felt uncomfortable.

\section{MATERIALS AND METHODS}

\subsection{Participants}

Participants were 89 students at Universiti Malaysia Terengganu. They comprised 63 females and 26 males. Their ages ranged between 20 and 23. In terms of English language proficienciy, most were considered to be at lowintermediate and intermediate levels, based on their Malaysian University English Test (MUET) scores of Band 2 and Band 3 out of the possible Band 6. They already belonged to four intact groups and were taking an English course to fulfill part of the university's requirements. The English course they were taking is normally conducted via face-to-face sessions in the classroom for 14 weeks. They had already attended the sessions for five weeks. However, the country was hit by the Covid-19 pandemic, and in response the Malaysian government enforced the Movement Control Order. In line with the enforcement, the university decided that all classes be conducted online completely. For the remaining nine weeks, participants attended online classes on Google Classroom. Participants took part in the online survey on a voluntary basis after they were informed of it and given a link to the survey via a messaging app.

\subsection{Questionnaire}

The questionnaire was adapted from the ones used by Darma Putra (2020) [34], Hamzat (2020) [3], Abd Manan and Hanafi (2019) [20], and Weng, Yang, Ho and Su (2018) [35], who based their item constructions on the technology acceptance model proposed by Davis (1989) [16]. The questionnaire consisted of 20 items, divided into four sections. Section 1 asked participants to provide some demographic details such as gender and English proficiency level. Section 2 asked participants to rate their perceptions regarding Google Classroom's ease of use. Section 3 asked them to rate their perceptions on Google Classroom's usefulness. The last section asked them to rate their intention to use Google Classroom. The distribution of items under each section is as shown in Table 1. For items in Section 2 to 4, the responses used were based on a five-point Likert scale, ranging from 1 (Strongly Disagree) to 5 (Strongly Agree).

The questionnaire was created using Google Form and could be accessed online. It allowed participants to provide their responses by clicking the chosen option for each item. When all items were anwered, the questionnaire could be submitted by participants by clicking the Submit button at the bottom of the form. Their responses were then automatically recorded.

\subsection{Procedure}

At the end of the semester after students had submitted all the assignments, the researcher sent all of them a text message via a messaging app, inviting them to take part in a survey. The researcher explained the purpose of the study and the survey. Also included in the text message was the link to the online questionnaire.

Table 1 Distribution of Questionnaire Items

\begin{tabular}{|c|c|c|}
\hline Component & $\begin{array}{c}\text { Number of } \\
\text { Items }\end{array}$ & Sample Item \\
\hline Perceived Ease of Use & 6 & It is easy for me to sign on to Google Classroom \\
\hline Perceived Usefulness & 6 & $\begin{array}{l}\text { Google Classroom allows me to interact with my lecturer and other } \\
\text { students effectively }\end{array}$ \\
\hline Intention to Use & 4 & I prefer learning through Google Classroom instead of face-to-face \\
\hline
\end{tabular}


Table 2 Criteria for Interpreting the Results

\begin{tabular}{cccccc}
\hline Measurement & & \multicolumn{4}{c}{ Degree of Agreement } \\
& Strongly Agree & Agree & Neutral & Disagree & Strongly Disagree \\
\hline Mean & $5-4.20$ & $4.19-3.40$ & $3.39-2.60$ & $2.59-1.80$ & $1.79-1$ \\
\hline
\end{tabular}

The researcher explained in the message that participation was not compulsory but voluntary, and that their clicking the link would indicate their consent. The researcher also mentioned that if students decided to participate, they had seven days to do so. After the seven days had passed, the researcher downloaded the questionnaire responses in Microsoft Excel format for analysis.

\subsection{Analysis}

Responses from the questionnaire were analyzed using Microsoft Excel Version 2010 for Microsoft 365 with Analysis Tool Pack Add-on installed. Data were analyzed to yield descriptive statistics. The criteria for interpreting the results, adopted from Al-Mekhlafi (2020) [4], are as shown in Table 2.

\section{RESULTS AND DISCUSSION}

There were 129 students in the English course, and all were invited to take part in the survey. However, only 89 completed the questionnaire, representing a response rae of $69 \%$. The questionnaire was validated and internal consistency was found to be high (Cronbach's $\alpha=.94)$.

\subsection{Demographic Details}

Demographic details of participants are as shown in Table 3.

Table 3 Demographic Information

\begin{tabular}{llcc}
\hline \multicolumn{1}{c}{ Item } & Values & Frequency & Percentage \\
\hline Gender & Male & 26 & $29 \%$ \\
& Female & 63 & $71 \%$ \\
Age & $20-21$ & 43 & $48 \%$ \\
& $22-23$ & 46 & $52 \%$ \\
MUET & Band 1 & 1 & $1 \%$ \\
Score & Band 2 & 41 & $46 \%$ \\
& Band 3 & 35 & $39 \%$ \\
Knowledge & Band 4 & 12 & $14 \%$ \\
of Internet & Gery Good & 11 & $12 \%$ \\
Technology & Neutral & 59 & $66 \%$ \\
& Low & 17 & $19 \%$ \\
& & 2 & $2 \%$ \\
\hline
\end{tabular}

\subsection{Overall Attitudes of Students towards Google Classroom}

The main focus of this study was to determine the attitudes of Malaysian university students towards the use of Google Classroom as their LMS. The 16 items concerning the attitudes were grouped under three main components: perceived ease of use, perceived usefulness, and intention to use. The results obtained from the analysis are as shown in Table 4. It can be seen that the component "perceived ease of use" had the highest mean score (4.23) and the component "intention to use" had the lowest mean score (3.86).

Table 4 Mean and Standard Deviation of Factors

\begin{tabular}{lcccl}
\hline Component & N & Mean & $\begin{array}{c}\text { Std. } \\
\text { Deviation }\end{array}$ & $\begin{array}{c}\text { Degree of } \\
\text { Agreement }\end{array}$ \\
\hline $\begin{array}{l}\text { Perceived } \\
\text { Ease of Use }\end{array}$ & 89 & 4.23 & 0.61 & $\begin{array}{l}\text { Strongly } \\
\text { Agree }\end{array}$ \\
$\begin{array}{l}\text { Perceived } \\
\text { Usefulness }\end{array}$ & 89 & 3.92 & 0.76 & Agree \\
$\begin{array}{l}\text { Intention to } \\
\text { Use }\end{array}$ & 89 & 3.86 & 0,83 & Agree \\
\hline
\end{tabular}

\subsection{Attitudes of Students towards Google Classroom's Ease of Use}

To determine participants' perceptions of Google Classroom's ease of use (research question 1), their responses to six items relating to perceived ease of use were analysed. The item statements and participants' responses are as shown in Table 5, arranged in descending order. The average mean of participants' responses under the component "perceived ease of use" was 4.23 (84.6\%). The means of the items ranged between 4.31 and 4.04. Item with the highest rating was "It is easy for me to sign on to Google Classroom", while the lowest was "It is easy for me to navigate around on Google Classroom". 
Table 5 Perceived Ease of Use

\begin{tabular}{|c|c|c|c|c|c|c|c|c|c|c|c|c|c|}
\hline \multirow[t]{2}{*}{$\begin{array}{l}\text { Perceived } \\
\text { Ease of Use }\end{array}$} & \multicolumn{2}{|c|}{$\begin{array}{l}\text { Strongly } \\
\text { Disagree }\end{array}$} & \multicolumn{2}{|c|}{ Disagree } & \multicolumn{2}{|c|}{ Neutral } & \multicolumn{2}{|c|}{ Agree } & \multicolumn{2}{|c|}{$\begin{array}{l}\text { Strongly } \\
\text { Agree }\end{array}$} & \multirow[t]{2}{*}{ Mean } & \multirow[t]{2}{*}{ SD } & \multirow[t]{2}{*}{$\begin{array}{l}\text { Degree of } \\
\text { Agreement }\end{array}$} \\
\hline & $\mathbf{F}$ & $\%$ & $\mathbf{F}$ & $\%$ & $\mathbf{F}$ & $\%$ & $\mathbf{F}$ & $\%$ & $\mathbf{F}$ & $\%$ & & & \\
\hline $\begin{array}{l}\text { It is easy for } \\
\text { me to sign on } \\
\text { to Google } \\
\text { Classroom }\end{array}$ & 0 & $0 \%$ & 0 & $0 \%$ & 7 & $8 \%$ & 47 & $53 \%$ & 35 & $39 \%$ & 4.31 & 0.61 & $\begin{array}{l}\text { Strongly } \\
\text { Agree }\end{array}$ \\
\hline $\begin{array}{l}\text { It is easy for } \\
\text { me to access } \\
\text { course } \\
\text { materials in } \\
\text { Google } \\
\text { Classroom }\end{array}$ & 0 & $0 \%$ & 0 & $0 \%$ & 2 & $2 \%$ & 57 & $64 \%$ & 30 & $34 \%$ & 4.31 & 0.51 & $\begin{array}{l}\text { Strongly } \\
\text { Agree }\end{array}$ \\
\hline $\begin{array}{l}\text { It is easy for } \\
\text { me to receive } \\
\text { the } \\
\text { assignments in } \\
\text { Google } \\
\text { Classroom }\end{array}$ & 0 & $0 \%$ & 1 & $1 \%$ & 3 & $3 \%$ & 52 & $58 \%$ & 33 & $37 \%$ & 4.31 & 0.60 & $\begin{array}{l}\text { Strongly } \\
\text { Agree }\end{array}$ \\
\hline $\begin{array}{l}\text { It is easy for } \\
\text { me to submit } \\
\text { the } \\
\text { assignments in } \\
\text { Google } \\
\text { Classroom }\end{array}$ & 0 & $0 \%$ & 1 & $1 \%$ & 7 & $8 \%$ & 47 & $53 \%$ & 34 & $38 \%$ & 4.28 & 0.66 & $\begin{array}{l}\text { Strongly } \\
\text { Agree }\end{array}$ \\
\hline $\begin{array}{l}\text { It is easy for } \\
\text { me to learn } \\
\text { how Google } \\
\text { Classroom } \\
\text { works as a } \\
\text { learning } \\
\text { system }\end{array}$ & 0 & $0 \%$ & 0 & $0 \%$ & 12 & $13 \%$ & 52 & $58 \%$ & 25 & $28 \%$ & 4.15 & 0.63 & Agree \\
\hline $\begin{array}{l}\text { It is easy for } \\
\text { me to navigate } \\
\text { around in } \\
\text { Google } \\
\text { Classroom }\end{array}$ & 0 & $0 \%$ & 1 & $1 \%$ & 15 & $17 \%$ & 52 & $58 \%$ & 21 & $24 \%$ & 4.04 & 0.67 & Agree \\
\hline Average & & & & & & & & & & & 4.23 & 0.61 & $\begin{array}{l}\text { Strongly } \\
\text { Agree }\end{array}$ \\
\hline
\end{tabular}

\subsection{Attitudes of Students towards Google Classroom's Usefulness}

To determine participants' perceptions of Google Classroom's usefulness (research question 2), their responses to six items relating to perceived usefulness were analysed. The item statements and participants' responses are as shown in Table 6, arranged in descending order. The average mean of participants' responses under the component "perceived ease of use" was 3.92 (78.4\%). The means of the items ranged between 4.19 and 3.76. Item with the highest rating was "Google classroom allows me to submit my assignments quickly and on time", while item with the lowest rating was "Google classroom increases my learning motivation".
The average mean of 4.23 for items under the component "perceived ease of use" translated into a very high degree of agreement (Strongly Agree). It can be suggested that participants considered Google Classroom as very easy to use. In comparison with the results from a recent study by Darma Putra (2020) [34], participants in the present study rated Google Classroom with regards to its ease of use much higher. In the study by Darma Putra, the average mean for "ease of use" was only 3.52. 
Table 6 Perceived Usefulness

\begin{tabular}{|c|c|c|c|c|c|c|c|c|c|c|c|c|c|}
\hline \multirow[t]{2}{*}{$\begin{array}{l}\text { Perceived } \\
\text { Usefulness }\end{array}$} & \multicolumn{2}{|c|}{$\begin{array}{l}\text { Strongly } \\
\text { Disagree }\end{array}$} & \multicolumn{2}{|c|}{ Disagree } & \multicolumn{2}{|c|}{ Neutral } & \multicolumn{2}{|c|}{ Agree } & \multicolumn{2}{|c|}{$\begin{array}{c}\text { Strongly } \\
\text { Agree }\end{array}$} & \multirow[t]{2}{*}{ Mean } & \multirow[t]{2}{*}{ SD } & \multirow[t]{2}{*}{$\begin{array}{c}\text { Degree of } \\
\text { Agreement }\end{array}$} \\
\hline & $\mathbf{F}$ & $\%$ & $\mathbf{F}$ & $\%$ & $\mathbf{F}$ & $\%$ & $\mathbf{F}$ & $\%$ & $\mathbf{F}$ & $\%$ & & & \\
\hline $\begin{array}{l}\text { Google } \\
\text { Classroom } \\
\text { allows me to } \\
\text { submit my } \\
\text { assignments } \\
\text { quickly and on } \\
\text { time. }\end{array}$ & 0 & $0 \%$ & 0 & $0 \%$ & 10 & 115 & 52 & $58 \%$ & 27 & $30 \%$ & 4.19 & 0.62 & Agree \\
\hline $\begin{array}{l}\text { I feel } \\
\text { comfortable } \\
\text { interacting } \\
\text { with my } \\
\text { lecturer in } \\
\text { Google } \\
\text { Classroom. }\end{array}$ & 0 & $0 \%$ & 1 & $1 \%$ & 21 & $24 \%$ & 43 & $48 \%$ & 24 & $27 \%$ & 4.01 & 0.75 & Agree \\
\hline $\begin{array}{l}\text { Learning } \\
\text { through } \\
\text { Google } \\
\text { Classroom is } \\
\text { fun and } \\
\text { interesting. }\end{array}$ & 0 & $0 \%$ & 1 & $1 \%$ & 25 & $28 \%$ & 43 & $48 \%$ & 20 & $27 \%$ & 3.92 & 0.74 & Agree \\
\hline $\begin{array}{l}\text { Google } \\
\text { Classroom has } \\
\text { made me more } \\
\text { productive. }\end{array}$ & 1 & $1 \%$ & 5 & $6 \%$ & 20 & $22 \%$ & 44 & $49 \%$ & 19 & $21 \%$ & 3.84 & 0.86 & Agree \\
\hline $\begin{array}{l}\text { Google } \\
\text { Classroom } \\
\text { allows me to } \\
\text { interact with } \\
\text { the lecturer and } \\
\text { with other } \\
\text { students } \\
\text { effectively. }\end{array}$ & 0 & $0 \%$ & 3 & $3 \%$ & 33 & $37 \%$ & 34 & $38 \%$ & 19 & $21 \%$ & 3.78 & 0.82 & Agree \\
\hline $\begin{array}{l}\text { Google } \\
\text { Classroom } \\
\text { increases my } \\
\text { learning } \\
\text { motivation. }\end{array}$ & 0 & $0 \%$ & 4 & $4 \%$ & 28 & $31 \%$ & 42 & $47 \%$ & 15 & $17 \%$ & 3.76 & 0.78 & Agree \\
\hline Average & & & & & & & & & & & 3.92 & 0.76 & Agree \\
\hline
\end{tabular}

The average mean of 3.92 for items under the component "perceived usefulness" still indicated a high degree of agreement (Agree). However, the average mean for this component was lower than that of the component "perceived ease of use". It can be suggested that, although participants did not rate Google Classroom's usefulness as high it its ease of use, they still considered the online system as highly useful. In comparison with the results from a recent study by Darma Putra (2020) [34], participants in the present study rated Google Classroom with regards to its usefulness much higher. In the study by Darma Putra, the average mean for "ease of use" was only 3.22 .

\subsection{Students' Intention to Use Google Classroom}

To determine participants' intention to use Google Classroom (research question 3), their responses to four items relating to intention to use were analysed. The item statements and participants' responses are as shown in Table 7, arranged in descending order. The average mean of participants' responses under the component "intention to use" was $3.86(77.2 \%)$. The means of the items ranged between 4.03 and 3.45. Item with the highest rating was "I would recommend other courses to use Google classroom", while item with the lowest rating was "I prefer learning through Google classroom instead of face-toface". 
Table 7 Intention to Use

\begin{tabular}{|c|c|c|c|c|c|c|c|c|c|c|c|c|c|}
\hline \multirow[t]{2}{*}{$\begin{array}{c}\text { Intention to } \\
\text { Use }\end{array}$} & \multicolumn{2}{|c|}{$\begin{array}{l}\text { Strongly } \\
\text { Disagree }\end{array}$} & \multicolumn{2}{|c|}{ Disagree } & \multicolumn{2}{|c|}{ Neutral } & \multicolumn{2}{|c|}{ Agree } & \multicolumn{2}{|c|}{$\begin{array}{l}\text { Strongly } \\
\text { Agree }\end{array}$} & \multirow[t]{2}{*}{ Mean } & \multirow[t]{2}{*}{ SD } & \multirow[t]{2}{*}{$\begin{array}{l}\text { Degree of } \\
\text { Agreement }\end{array}$} \\
\hline & $\mathbf{F}$ & $\%$ & $\mathbf{F}$ & $\%$ & $\mathbf{F}$ & $\%$ & $\mathbf{F}$ & $\%$ & $\mathbf{F}$ & $\%$ & & & \\
\hline $\begin{array}{l}\text { I would } \\
\text { recommend } \\
\text { other courses } \\
\text { to use Google } \\
\text { classroom. }\end{array}$ & 0 & $0 \%$ & 3 & $3 \%$ & 15 & $17 \%$ & 47 & $53 \%$ & 24 & $27 \%$ & 4.03 & 0.76 & Agree \\
\hline $\begin{array}{l}\text { Google } \\
\text { classroom is } \\
\text { suitable for } \\
\text { language } \\
\text { courses }\end{array}$ & 0 & $0 \%$ & 3 & $3 \%$ & 17 & $19 \%$ & 47 & $53 \%$ & 22 & $25 \%$ & 3.99 & 0.76 & Agree \\
\hline $\begin{array}{l}\text { I prefer Google } \\
\text { classroom } \\
\text { instead of other } \\
\text { online learning } \\
\text { methods. }\end{array}$ & 0 & $0 \%$ & 4 & $4 \%$ & 18 & $20 \%$ & 43 & $48 \%$ & 24 & $27 \%$ & 3.98 & 0.81 & Agree \\
\hline $\begin{array}{l}\text { I prefer } \\
\text { learning } \\
\text { through } \\
\text { Google } \\
\text { classroom } \\
\text { instead of face- } \\
\text { to-face. }\end{array}$ & 4 & $4 \%$ & 7 & $8 \%$ & 37 & $42 \%$ & 27 & $30 \%$ & 14 & $16 \%$ & 3.45 & 1 & Agree \\
\hline Average & & & & & & & & & & & 3.86 & 0.83 & Agree \\
\hline
\end{tabular}

The average mean of 3.86 for items under the component "intention to use" still indicated a moderately high degree of agreement (Agree). However, the average mean for this component was lower than those of the other factors ("perceived ease of use", "perceived usefulness"). It can be suggested that, although participants did not rate their intention to use Google Classroom as high as the other two factors, they were nevertheless satisfied with the features available in the platform and felt motivated to continue using it. In comparison with the results from a recent study by Darma Putra (2020) [34], participants in the present study rated their intention to use Google Classroom much higher. One of the similar items in both the present study and in Drama Putra's study was on recommending the use of Google Classroom for other courses. The mean in the present study was 4.03, while in that of Darma Putra 3.21. Another similar item was on Google Classroom being preferred to other methods. In the present study, the mean was 3.98. In contrast, in Darma Putra's study, the mean was only 3.10 .

\subsection{Limitations and Recommendations}

In this study, there were some limitations that may be addressed in future studies. The first limitation was the small number of participants, which was 89. It may be recommended that the number of participants in future studies be increased threefold for improved reliability and validity. A large number of participants were used in other similar studies. In Hamzat (2020) [3], the number of Nigerian participants was 252. In Al-Maroof and Al-
Emran (2018) [29], the number of Omani participants was 337. The second limitation was the exclusion of correlative analysis to determine if factors such as age and gender and others were significant with respect to the attitudes towards Google Classroom. It may be recommended that in future studies these factors be analysed for deeper breakdown of the attitudes. Some of these factors were investigated in other studies, with Al-Mekhlafi (2020) [4] examining whether Yemeni students' attitudes towards Google Classroom differed according to level of tertiary education, and Al-Mekhlafi (2020) [4] and Hamzat (2020) [3] examining whether attitudes of Yemeni and Nigerian students respectively differed according to gender. Two factors that may be examined in future studies are participants' English proficiency levels and their perceived knowledge of the Internet technology. The third and final limitation was the absence of analysis that established relationship between attitudes towards Google Classroom and students' academic performance when using the platform. It may be recommended that in future studies this analysis be carried out to determine if participants' positive attitudes correlate with their good performance and vice versa. An almost similar scope was present in Albashtawi and Al Bataineh (2020) [17], whereby the effect of Google Classroom on reading and writing performance of EFL students in Jordan were investigated. 


\section{CONCLUSION}

The present study aimed to determine the attitudes of students of Unversiti Malaysia Terengganu, Malaysia, towards the use of Google Classroom as their LMS. Based on the results obtained from the questionnaire, it was found that all participants had highly positive views towards the system. They considered Google Classroom as very easy to use, with this factor having the highest mean. They also believed that Google Classroom is highly useful in that it helped them be more productive, allowed them to access materials conveniently and submit assignments quickly, and enabled them to interact with the lecturer and other students. They also indicated their high intention to use Google Classroom. Their satisfaction with its use as LMS motivated them to want to continue using the online platform, to the point of preferring it to face-to-face instructions and even suggesting its implementation for other courses. It can be suggested that all participants found Google Classroom easy to use, useful, and worth using.

\section{REFERENCES}

[1] Z. J. Zhang, Influence of Modern Technology on the Educational System. Advanced Materials Research 1030-1032 (2014): 2746-49. DOI: https://doi.org/10.4028/www.scientific.net/amr.10301032.2746

[2] R. Raja and P. C. Nagasubramani, Impact of modern technology in education. Journal of Applied and Advanced Research,3(1) (2018) 33-35. DOI: https://doi.org/10.21839/jaar.2018.v3is1.165

[3] A. A. Hamzat, Students'attitude and Perceived Usefulness of Google Classroom for Learning in Oyo State Colleges, Nigeria. Capital Journal of Educational Studies (Cajes), 6(2) (2020) 46-55. DOI: http://fctcoezjournals.Org/Index.Php/Cajes

[4] M. A. A. Al-Mekhlafi, An Exploration of Yemeni University Students' Attitudes Towards Learning Linguistic Courses Using Google Classroom. Millennium Journal of English Literature, Linguistics and Translation, 1(1), (2020) 1-16. DOI: https://doi.org/10.47340/mjellt.v1i1.1.2020

[5] J. J. C. Sánchez and E. C. Alemán Teachers' opinion survey on the use of ICT tools to support attendance-based teaching. Computers \& Education, 56(3) (2011) 911-915. DOI: https://doi.org/10.1016/j.compedu.2010.11.005

[6] A. G. Almekhlafi, The effect of computer assisted language learning (CALL) on United Arab Emirates English as a foreign language (EFL) school students' achievement and attitude. Journal of Interactive learning research,17(2) (2006) 121-142. DOI: https://www.learntechlib.org/p/64230/

[7] A. K. A. Awad and S. M. S. Alkaraki, Attitudes of EFL students towards using computers in learning English. English for Specific Purposes, 13(37) (2013) $1-20$.

[8] O. Kitchakarn, EFL Learners' Attitudes towards Using Computers as a Learning Tool in Language Learning. Turkish Online Journal of Educational Technology-TOJET, 14(2) (2015) 52-58.

[9] D. S. Yang, A Study Of Students' Atitudes Towards Using ICT In Asocial Construtivist Environment Australas. J. Educ. Technol, 50 (2017). DOI: https://doi.org/10.14742/ajet.2890

[10] S. Dhawan, Online learning: A panacea in the time of COVID-19 crisis. Journal of Educational Technology Systems, 49(1) (2020) 5-22. DOI: https://doi.org/10.1177/0047239520934018

[11] V. Singh and A. Thurman, How many ways can we define online learning? A systematic literature review of definitions of online learning (19882018). American Journal of Distance Education, 33(4) (2019), 289-306. DOI: https://doi.org/10.1080/08923647.2019.1663082

[12] K. Ansong-Gyimah, Students' Perceptions and Continuous Intention to Use E-Learning Systems: The Case of Google Classroom. International Journal of Emerging Technologies in Learning (iJET), 15(11) (2020) 236-244. doi:http://dx.doi.org/10.3991/ijet.v15i11.12683

[13] N. Abedalaziz, S. Jamaluddin and C. H. Leng, Measuring attitudes toward computer and internet usage among postgraduate students in Malaysia. Turkish Online Journal of Educational TechnologyTOJET, 12(2) (2013) 200-216. DOI: http://www.tojet.net/articles/v12i2/12219.pdf

[14] Aldiab, A., Chowdhury, H., Kootsookos, A., Alam, F., \& Allhibi, H. (2019). Utilization of Learning Management Systems (LMSs) in higher education system: A case review for Saudi Arabia. Energy Procedia, 160 (2019) 731-737. DOI: 10.1016/j.egypro.2019.02.186.

[15] S. Lonn and S. D. Teasley, Saving time or innovating practice: Investigating perceptions and uses of Learning Management Systems. Computers \& education, 53(3) (2009) 686-694.

[16] F. D. Davis, Perceived usefulness, perceived ease of use, and user acceptance of information technology. MIS Q. 13 (3) (1989) 319. DOI: https://doi.org/10.2307/249008 
[17] A. Albashtawi and K. Al Bataineh, The effectiveness of google classroom among EFL students in Jordan: an innovative teaching and learning online platform. International Journal of Emerging Technologies in Learning (iJET), 15(11) (2020) 78-88. DOI:http://dx.doi.org/10.3991/ijet.v15i11.12865

[18] A. Wijaya, Analysis of factors affecting the use of Google Classroom to support lectures. In The 5th International Conference on Information Technology and Engineering Application (ICIBA2016). Bina Darma University. 2016.

[19] S. Iftakhar, Google classroom: what works and how. Journal of Education and Social Sciences, 3(1) (2016) 12-18.

[20] N. Z. Abd Manan and H. F. Hanafi, Google Classroom: Student's Acceptance using UTAUT Model. Journal of Applied Arts, 1(1) (2019) 64-72. DOI:

https://journal.scientiaca.org/index.php/Jappa/article/vie $\mathrm{w} / 40$

[21] M. Sepyanda, M. (2018). STUDENTS'ATTITUDE TOWARD THE USE OF GOOGLE CLASSROOM ON TRANSLATION SUBJECT IN ENGLISH DEPARTMENT OF FKIP UMMY SOLOK. English Language Teaching and Research, 2(1) (2018). DOI: http://ejournal.unp.ac.id/index.php/eltar/article/view/10 2661

[22] R. Hulse, The Use and Implementation of Google Classroom in a Japanese University. The Centre for the Study of English Language Teaching Journal, 7, (2017) 71-105.

[23] A. Izenstark and K. L. Leahy, Google classroom for librarians: features and opportunities. Library $\mathrm{Hi}$ Tech News. $2015 . \quad$ DOI: http://dx.doi.org/10.1108/LHTN-05-2015-0039

[24] K. A. Azhar and N. Iqbal, Effectiveness of Google Classroom: Teachers' Perceptions. PRIZREN SOCIAL SCIENCE JOURNAL, 2(2), (2018) 52-66.

[25] S. Hemrungrote, P. Jakkaew and S. Assawaboonmee, Deployment of Google Classroom to enhance SDL cognitive skills: A case study of introduction to information technology course. In 2017 International Conference on Digital Arts, Media and Technology (ICDAMT) IEEE. (2017) 200-204. DOI: 10.1109/ICDAMT.2017.7904961

[26] K. R. Heggart and J. Yoo, Getting the most from Google Classroom: A pedagogical framework for tertiary educators. Australian Journal of Teacher Education, 43(3) (2018) 9.
[27] R. A. S. Al-Maroof and M. Al-Emran, Students acceptance of Google classroom: An exploratory study using PLS-SEM approach. International Journal of Emerging Technologies in Learning (iJET), 13(06) (2016) 112-123. DOI: 10.3991/ijet.v13i06.8275

[28] Z. M. Khalil, EFL Students' Perceptions towards Using Google Docs and Google Classroom as Online Collaborative Tools in Learning Grammar. Applied Linguistics Research Journal, 2(2) (2018) 33-48. DOI: https://doi.org/10.14744/alrj.2018.47955

[29] R. A. S. Al-Maroof and M. Al-Emran, Students acceptance of Google classroom: An exploratory study using PLS-SEM approach. International Journal of Emerging Technologies in Learning (iJET), 13(06) (2018) $112-123$ doi:http://dx.doi.org/10.3991/ijet.v13i06.8275

[30] I. N. Mohd Shaharanee, J. Jamil and S. S. Mohamad Rodzi, The application of Google Classroom as a tool for teaching and learning. Journal of Telecommunication, Electronic and Computer Engineering, 8(10) (2016) 5-8.

[31] W. Reinhardt, C. Mletzko, P. Sloep and H. Drachsler. Understanding the meaning of awareness in Research Networks. 2013.

[32] L. J. Awuah, Supporting 21st-Century Teaching and Learning: The Role of Google Apps for Education (GAFE). Journal of Instructional Research, 4 (2015) 12-22.

[33], A. S. Bhuvaneswari and T. Padmanaban, Attitude of senior secondary students towards elearning. Elixir Educational Technology, 51 (2012) 10886-10888.

[34] I. N. T. D. Putra Students' Attitudes in Learning English for Tourism Using Google Classroom in Mataram Tourism College. Jo-ELT (Journal of English Language Teaching) Fakultas Pendidikan Bahasa \& Seni Prodi Pendidikan Bahasa Inggris IKIP,7(1) (2020) 9-17. DOI: https://doi.org/10.33394/joelt.v7i1.2735

[35] F. Weng, R. Yang, H. Ho and H. Su, A TAMBased Study of the Attitude towards Use Intention of Multimedia among School Teachers. Applied System Innovation, 1(3), (2018) 36. DOI: http://dx.doi.org/10.3390/asi1030036 